\title{
Assessment of Gear Efficiency for Harvesting Artisanal Giant Freshwater Prawn (Macrobrachium Rosenbergii de Man) Fisheries from the Sundarbans Mangrove Ecosystem in Bangladesh
}

Biplab Kumar Shaha ${ }^{1}$, Md. Mahmudul Alam²*, H. M. Rakibul Islam ${ }^{3}$, Lubna Alam ${ }^{4}$, Alokesh Kumar Ghosh ${ }^{5}$, Khan Kamal Uddin Ahmed ${ }^{6}$, Mazlin Mokhtar ${ }^{7}$

${ }^{1}$ Fisheries and Marine Resource Technology Discipline, Khulna University, Bangladesh

${ }^{2}$ Doctoral Student, Institute for Environment and Development (LESTARI), National University of Malaysia (UKM), Malaysia

${ }^{3}$ Scientific Officer, Bangladesh Fisheries Research Institute, Shrimp Research Station, Bagerhat, Bangladesh

${ }^{4}$ Research Fellow, Institute for Environment and Development (LESTARI), National University of Malaysia (UKM), Malaysia

${ }^{5}$ Assistant Professor, Fisheries and Marine Resource TechnologyDiscipline, Khulna University, Bangladesh

${ }^{6}$ Chief Scientific Officer, Bangladesh Fisheries Research Institute. Shrimp Research Station, Bagerhat, Bangladesh

${ }^{7}$ Professor, Institute for Environment and Development (LESTARI), National University of Malaysia (UKM), Malaysia

\section{Citation Reference:}

Shaha, B.K., Alam, M.M., Islam, H.M.R., Alam, L., Ghosh, A.K., Ahmed, K.K.U., and Mokthar, M. 2014. Assessment of Gear Efficiency for Harvesting Artisanal Giant Freshwater Prawn (Macrobrachium Rosenbergii De Man) Fisheries from the Sundarbans Mangrove Ecosystem in Bangladesh. Research Journal of Fisheries and Hydrobiology, 9(2): 1126-1139. http://www.aensiweb.com/old/jasa/2JASA February 2014.html

This is a pre-publication copy.

The published article is copyrighted by the publisher of the journal.

* Corresponding author, email: rony000@gmail.com 


\title{
Assessment of Gear Efficiency for Harvesting Artisanal Giant Freshwater Prawn (Macrobrachium Rosenbergii de Man) Fisheries from the Sundarbans Mangrove Ecosystem in Bangladesh
}

\begin{abstract}
The Sundarnbans mangrove forest has been an immense source of aquatic resources from time immemorial. Among the resources, harvesting of Giant Freshwater Prawn (Macrobrachium rosenbergii de Man 1879) plays an important role in the economy of the country, therefore, this investigation was carried out to assess the Gear Efficiency for Harvesting Artisanal Giant Freshwater Prawn Fisheries from the Sundarbans Mangrove Ecosystem in Bangladesh. Four types of non-mechanized crafts made of fourteen types of wood were found in harvesting Giant Freshwater Prawn. Crafts were varied from $6.25 \pm 0.35$ to $8.2 \pm 0.71 \mathrm{~m}$ in length, $1.1 \pm 0.14$ to $1.75 \pm 0.36 \mathrm{~m}$ in breadth and $0.65 \pm 1.07$ to $1.55 \pm 3.16 \mathrm{~m}$ in depth with a carrying capacity of $0.40-1.00 \mathrm{MT}$ with an economic life of $10 \pm 2.11$ years. A total of eight types of gears, namely, Hookline, Behundijal, Badhajal, Charpata, Chandijal, Gillnet, Kathijal and KhalPata were found in Giant Freshwater Prawn fishing. Among them the Hookline was the only main primary active Giant Freshwater Prawn fishing gear while the rest of the seven gears were multi-species gears which harvest Giant Freshwater Prawn as a by-catch. Only $13.6 \%$ of 1,989 fishers were found to use Hookline; the rest, $86.4 \%$ of fishers used the seven other gears. They only harvest 3.24\% Giant Freshwater Prawn as a bycatch. The highest daily harvest volume per boat $\left(\mathrm{kg} \mathrm{day}^{-1}\right.$ boat $\left.^{-1}\right)$ was $1.00 \pm 0.96$ for the Kathijal followed by $0.99 \pm 0.27$ for the Badhajal and $0.99 \pm 0.42$ for the Hookline. The highest annual catch per boat $\left(\mathrm{kg}\right.$ boat $\left.{ }^{-1} \mathrm{yr}^{-1}\right)$ which was $172.80 \pm 0.29$ was recorded for the Hookline followed by $172.24 \pm 0.54$ for the Chandijal and the lowest $(152.08 \pm 0.21)$ for the Khalpata. Total annual catch by all the eight gears surveyed was estimated at $1318.60 \pm 0.37 \mathrm{~kg}$ from 1,428 unit gears, 545 individual boats and 1,989 individual fishers. Based on the above scenario, Hookline showed the best performance among the 8 gears used for Giant Freshwater Prawn harvesting in the Sundarbans by the small-scale artisanal fishery. It is believed that the findings and the recommendations of this study will be helpful to policy makers in improving the current status of Giant Freshwater Prawn fishery and relevant livelihood as well as conserving the SME ecosystem.
\end{abstract}

Key word: Artisanal fisheries;Macrobrachium rosenbergii; Sundarbans Mangrove Ecosystem; Fishing Gear

\section{Introduction}

The reverie, Giant Freshwater Prawn Macrobrachium rosenbergii, locally called the Giant Freshwater Prawn, is one of the highest valued crustaceans in Bangladesh and also a highly valued product in international markets; almost all prawns are therefore exported, particularly to the USA, Japan, and Europe. Traditionally, freshwater prawns have been caught wild in ponds and marshes (Gain, 1998) through artisanal fisheries across the country including the Sundarbans Mangrove Ecosystem (SME) or Sundarbans Reserve Forest (SRF). It has been widely distributed in all types of freshwater habitats including the Sundarbans. It migrates to the coastal saline estuaries including the Sundarbans for breeding. The species is cultivated across the country in freshwater ponds for export. Between the late 1970s and the mid-1980s, a few pioneering farmers in Fakirhat Upazila(sub-district) in Bagerhat district developed Giant Freshwater Prawn farming technology in small rice-fields using mainly rain water and peripheral mud embankments (Rutherford, 1994). 
In 1976, Bangladesh exported a total of 3,800 mt of shrimps and prawns, and in just twenty years, this grew eightfold to $31,500 \mathrm{mt}$. Of this total, approximately $85 \%$ were cultured; half of them are from fresh water. These exports earned 248 million dollars, equivalent roughly to a 3\% share of the world's total shrimp/prawn exports (Vannuccini, 1999). Assuming that the royalty rate is only $12.5 \%$ of the gross value of the products, it can be calculated that the gross value of the fish products in 1990-91 was BDT 112 million (US\$ 2.8 million) (Islam, 2007). In addition, about BDT 30 million (US\$ 750,000) per annum is earned from 60 million $\mathrm{kg}$ of shrimps, mainly tiger prawns, from the Sundarbans and other coastal mangrove areas of Bangladesh (DoF, 2005; BBS, 2005). The revenue generated from fish products increased from Tk. 1.04 million (US\$ 26,000) in 1980-81 to BDT 14.3 million (US\$ 357,000) in 1990-91 (DoF, 1982; DoF, 1983; DoF, 1991; DoF, 1992; FAO, 2003; MoFL and DANIDA, 2001). An average of 67,195 boats with 165,270 fishermen annually visit the Sundarbans and fish for their livelihood (DoF, 2008a). Recent data reveals that the collection of "seed" prawns involves about 25,000 men, women and children (DoF, 2008b). Shell collection also contributes to the employment of young boys and girls (about 550 permit issues, each engaging 3-4 people each year). The number of shell collectors increases during the winter tourist season (Rahmanet al., 2003; Giasuddin, 2002).

Bangladesh exported 46,533 tons of prawn and shrimp in 2005 valued at US\$ 378 million in which 25-30\% was contributed by prawn (DoF, 2006). This figure is expected to rise with the increasing expansion of freshwater prawn cultivation into new area of Mymensingh district in the north-central part of Bangladesh (Ahmed et al., 2008). The total area under cultivation nationwide is estimated to be around 30,000 ha (Willams, 2003). A large number of fishing community is involved in Giant Freshwater Prawn fishing from the SME. While there is great potential for increasing family incomes through engaging in prawn cultivation, a number of factors might contribute to the vulnerability of prawn farmers including increased production costs, poor institutional support, and inadequate extension services (Ahmed, 2002); on the other hand, these factors are less effective in wild fishery.

With this view, it is essential to the development and management of a fishing unit to know the efficient ways of harvesting. However, no information is available on the fishery in general and fisheries economics in particular in the above context in the SME. The present study, therefore, was aimed at assessing the overall economic perspective of Giant Freshwater Prawn (Macrobrachium rosenbergii) fishery from the Sundarbans mangrove ecosystem of Bangladesh.

\section{Literature Review}

The existing literature on aquatic species in Bangladesh are, by large, focused on the farming aspects rather than fishery (Halimet al.,2001; Linget al., 1999; Huda et al., 2002; Aftabuzzaman, 1998; Thomas et al., 2001;Bhattacharya et al., 1999a and 1999b; Leung and Sharma, 2001; Ling et al., 2001; Shang et al., 2001). Most of the economic analyses carried out in the past in Bangladesh were concentrated on aquaculture production of Giant Freshwater Prawn or Bagda shrimps (Shah et al., 2000; Ito, 2002; Ahmed et al., 2008; Alamet al., 2007; Ahmed, 2001; UNEP, 1999; BCAS, 2001; Qudduset al., 2001; Manju, 1996). Exploration of the Sundarban mangroves dates back to the 16th century (Rollet, 1981); a large bulk of published literature exists on the Sundarbans of both India (Naskar and GuhaBakshi, 1987; Chaudhuri and Choudhury, 1994; Guhaet al., 1999) and Bangladesh (Seidenstickeret al., 1991; Hussain and Acharya, 1994; Islam and Wahab, 2005) covering 
many aspects of their habitat characteristics, flora, fauna (particularly fisheries), utilization, and management. However, little is known about the functional aspects of this ecosystem.

Information on the economic aspects of fisheries from the Sundarbans is scanty. However, a few review studies have reported fragmented information on fisheries economics of capture fisheries from the coastal waters and the Sundarbans mangrove ecosystem of Bangladesh (Hoqet al., 2001; Hoq, 2007; Hoqet al., 2006; Islam and Wahab, 2005; Islam, 2003; Ali et al., 2004; Haque, 2003; Islam and Haque, 2004). However, information available so far on the demographic features and the economic feasibility in terms of gear efficiency or economic performance are not adequate to get a clear idea on economic return of wild capture fisheries practiced around the inshore and offshore coastal waters around the SME (BOBP, 1994; BOBP, 1996). However, a number of studies particularly on demersal trawl fisheries in the Bay of Bengal have been undertaken to examine the stock status and scope for future development in harvest. Khan (1983), and White and Khan (1985) identified the capture fisheries of Bangladesh as complex and multi-species in nature with a number of species targeted by the fishery. The multiplicity of gear used by the fishers in Bangladesh is to maximize the level of exploitation of a variety of species at the same time using a single gear.

Bernacsek (2001) reported that the fishing grounds in the SME are located along the sea-forest boundary spanning an area of $90 \mathrm{~km}$ in length. An intense fishing activity is concentrated in some areas of about $2,250 \mathrm{~km}^{2}$ within $25 \mathrm{~km}$ from the shoreline and six heads of the estuaries of $960 \mathrm{~km}^{2}$. Chantarasri (1994) reported on the fish biology and life histories of the eleven most commercially important fish and crustacean species including Giant Freshwater Prawn (Macrobrachium rosenbergii). Bernacsek (2001) also reported the presence of artisanal fishery within the SME with small non-mechanized boats and 14 types of artisanal fishing gears. He reported two types of fishing gears for Giant Freshwater Prawn fishing, namely the angling hook (borshi) and the stick-hook (borshi) fishery using small low valued (BDT. $20 \mathrm{~kg}^{-1}$ ) Chakachingri (Penaeusindicus) as bait. The angling hook (borshi) is used during winter with an average daily catch of $1 \mathrm{~kg}$ (5-6 individuals) and fishers sold the catch at BDT. $400 \mathrm{~kg}^{-1}$. While the stick-hook is normally operated round the year by one fisherman for 6-10 hrs a day during spring tide periods (20-22 days month ${ }^{-1}$ ). It is used mainly in small rivers and canals in the upper parts of the estuarine of SME.

Hoq et al. (2003) described the fisheries structure and management in the SME and mentioned that at least 14 types of fishing gear are employed in SME, majority of which has a relatively high selectivity (mean number of major species caught $>10$ ). Meanwhile, Islam (2003) analyzed various issues of the coastal and marine fisheries of the Bay of Bengal, Bangladesh. Coastal and marine fisheries of the Bay of Bengal are briefly reviewed in this paper to provide a salient feature of the available information and resource base and to identify future research and management needs.

Artisanal fisheries range from localized subsistence fishing to intensive mobile fishing operations using 4 types of non-mechanized wooden crafts and 14 types of traditional gears (Hossain and Ahmed, 2006; Hagganet al., 2003, Haque, 1995). Among them, the Hookline is the only species specific gear used for harvesting Giant Freshwater Prawn in the SME. However, due to higher prices, almost all other gears are used to catch Giant Freshwater Prawn while catching white fish as a by-catch. The Hookline is a lure device, characterized with low capital investment and operating cost, easy to maintain and it requires less manpower to operate. The number of fishers and gears employed in catching Giant 
Freshwater Prawn in the SME in 2002 was 1,410 and 705 respectively (Haque, 2003). A number of locally available baits are used in catching Giant Freshwater Prawn considering availability, cost and stability in water (Bernacsek, 2001). Thus, most marginal fishers are involved in Giant Freshwater Prawn fishery with this gear. As fishing technique in the SME is characteristically one gear multi-species, thus, a huge quantity of Giant Freshwater Prawn are harvested as by-catch by other secondary gears.

Bangladeshi SME fishermen use indigenous fishing craft known as Nauka (country boat) operated manually by one or two fishermen, measuring approximately $7.06 \mathrm{~m}$ in length and $1.58 \mathrm{~m}$ in width. Although, a small quantity of mechanized boats has been developed for commercial fishing in the marine zone of the SME (Chowdhuryet al., 1993), such practice is completely absent for Giant Freshwater Prawn fishing inside the SME (Hossain and Ahmed, 2006; Haqueet al., 1993b). Boats are mainly constructed with Raintree, Khoi and Sunduri depending on the availability and financial capacity of the fishers (Hossain and Ahmed, 2006; Chowdhuryet al., 1993; Haqueet al., 1993).

\section{Methodology and Data Collection}

This study was conducted through several field surveys in the SME waters covering three administrative ranges (Fig. 1). The SME is located between longitudes $89^{\circ} 00^{\prime} \mathrm{E}$ and $89^{\circ} 55^{\prime}$ $\mathrm{E}$ and latitudes $21^{\circ} 30^{\prime} \mathrm{N}$ and $22^{\circ} 30^{\prime} \mathrm{N}$ at the south-west of Bangladesh, encompassing the mouth of the 6 estuaries, and numerous rivers, canals and creeks (Giri and Shrestha, 1996; Viju, 1995).

The study was conducted through 24 individual surveys in the SME of Bangladesh covering 16 river/canals and 32 locations (one-third area) of the Sundarbans along the Mongla-Passure-Dubla area within Sharankhola, Chandpai and Khulna ranges between January and December 2006 at a fortnightly interval (Table 1).

The data were collected by direct interviews of randomly selected 1,989 fishermen from 545 non-mechanized boats and 1,428 active gears from eight types of gear.

The data were analyzed through descriptive statistics (mean, range, standard deviation) by using the SPSS software. The seasonal and spatial variation in the catch was estimated by using the one-way ANOVA. The relationships between the variables were measured by using the Pearson's correlation and regression. To draw inference, 95\% confidence interval was used in the analysis.

\section{Methods of Giant Freshwater Prawn Fishing in SME}

\section{Mode of Gear Operation}

Hookline: The Hookline is a baited gear generally used by a single fisher per boat in rivers, small rivers and canals during spring tide phases throughout the SME. It is used with a small rod (stick), hook and line. About 4-7 sticks with hooks are employed to catch giant freshwater prawns in the SME. Hooks of various numbers, generally 12 in number, each with 2-2.2 $\mathrm{cm}$ in height are employed. It is operated in the daytime, mainly during high tide for 5-6 hrs/day. The fishermen mostly avoid operating this gear during the night mainly due to insecurity. 
Behundijal: It is a larger version of the Patajal used to catch small fish and crustaceans, which are weak swimmers. It is usually set towards the center of the river channel, and rarely near the shore. Hence, no external anchoring is used. It is hauled twice a day; only during low tide phases. The catch is quite low; juvenile shrimp constitute about $98 \%$ of the catch; the rest are juvenile finfish. It is set in every month in the small rivers of the Sundarbans areas during the time of spring tide. This net is set 2-3 times every 24 hours. Nets are set against the current by fastening the wings to a pair of heavy wooden anchors in deeper water areas, or two wooden poles in shallower water. The mouth of the net is kept open by 2 bamboo poles, fastened to the upper and lower lips of the mouth of the bag. A wooden barrel is tied to each end of the wing to serve as a buoy. The cod end is tied with a rope and a float is also attached to it to know the location. A small Balam boat with two men is required to set the net. Hauling is done when the tide runs and after emptying the contents may again be set against the prevailing tide. The fish comes with the tidal current, enters through the mouth and ends up in the bag. The catch consists of crabs, shrimps and many kinds of fresh and brackish water fishes. This net is highly destructive for juvenile fish, shrimp and crab species.

Charpatajal: It is operated in the rivers and khals of the SME. The net is potentially very effective (i.e. destructive) in small rivers and khals, as it is capable of catching virtually all fish, irrespective of size, present in Khals. The catch composition (i.e. Latescalcarifer, Plotosuscanius, Scatophagusaurgus, Jhonius spp., Mugil spp., Arius spp. etc.) is quite different from that of the set bagnets. It is used during spring tides. It is set in the intertidal zone of the rivers of the Sundarhans. The net is placed once a day and it remains under water during high tides. Poles are fixed during low tides along the lowest low tide line and the net is kept folded and embedded into the mud on the ground. The stout ground rope is tied to the poles at the base. The head rope may also be tied above in some places to facilitate the lifting of the net later on during the high tide. Food is given when the water of the tide rises on the net from 1 to $1.5 \mathrm{~m}$ in height; 4 to $5 \mathrm{~kg}$ of the rice particles, rice bran and sago are mixed with water and the mixture of these items are applied in the water as food to attract fish. When the high tide has reached the maximum level, fishermen go by boats, raise the net and tie the head rope above the level of water. Two to three fishermen are engaged to operate this net. When the tide turns and water recedes, the crabs, prawns and fishes are stranded and gathered.

Khalpatajal: It is similar to the Charpatajal in length and mesh size but slightly larger in breadth measuring about $4 \mathrm{~m}$. It is a rectangular net of 30-40 $\mathrm{m}$ in length, 2.5-3 $\mathrm{m}$ in breadth and $2-4 \mathrm{~cm}$ in mesh size, operated in estuarine creeks or khals in the Sundarbans.

Gillnet: It is circular in shape and catches fish by gilling or entanglement. Gillnets are anchored to the bottom so that they are not free to move with the water current. They are usually set in rivers and estuaries before the high tide. Sometimes, the net may serve as a barrier. The fish and crabs get entangled in its meshes. The length of the net depends on the amount of capital available to the operator.

Chandijal: It is a set gill net, mainly used in fishing of Hilsha from May to October. The net is designed for large open water bodies. The net is used for fishing as Shylong, Rui, Catla, Mrigel, Kalbasu, etc. It is made of several rectangular shaped 11-12 m pieces; joined together. The mesh size of the net is 1.75 to $5 \mathrm{~cm}$. Both sides of the net are locked with heavy nylon ropes along with floats and sinkers inversely. The net is weaved with nylon and polyester fibers. The net is either hanged with bamboo poles from both the sides over water, 
or it can be operated with the help of a boat. The set gill net is operated by 5-10 fishermen at a time.

Badhajal: This is a type of set bag net, resembling a trawl net, set in the tidal stream by attaching it to hold-fasts. It has a rectangular mouth kept open by two vertical bamboo poles. The net is held in a fishing position against the current by linking the extended sides of the net (wing tips) to hold-fasts by means of long bamboo poles and steel wires. The hold-fasts are two wooden stakes embedded some distance apart in the sea bed, so that the net is parallel to the direction of the current.

Kathijal: It is locally known as "Jakhijal" and also called "Khepla" or "Kheplajal". It is a conical shaped net with a variable size. The hauling string of the net is fixed at the narrow apical end of the cone. The lower end is folded, doubled up and attached to the net at intervals to form a series of pockets. The margins of the pockets are provided with iron weights as a sinker. These nets are thrown into the shallow or moderately deep water from the shore bank or from a slow moving boat. As soon as it is thrown, it goes down quickly due to the weight of the sinkers. When the net is hauled, the sinkers disturb the fish at the bottom, and make them enter the pockets and are secured there. This net requires a mostly smooth bottom for operation. All types of fish are caught by this gear.

\section{Performance of Gears}

Artisanal fisheries in the SME range from localized subsistence fishing to intensive mobile fishing operations using simple non-mechanized crafts and traditional gears. Some gears are species specific and the rest are multi-species. Among the eight types of gears operated in the SME during the present study, only a single gear, namely Hookline, was the primary gear used in Giant Freshwater Prawn catching. However, the rest of the seven gears were secondary in nature, used in Giant Freshwater Prawn harvest as a by-catch. Only $13.60 \%$ of 1,989 fishers were found to use Hookline in Giant Freshwater Prawn fishing inside the SME. However, the majority of the fishers $(86.4 \%)$ used the seven other gears in catching other fish and shrimp as target species and harvested only 3.24\% Giant Freshwater Prawn as a by-catch. About $29.66 \%$ of the fishers catched Giant Freshwater Prawn and other fish and shrimp, 20.83\% fished both Giant Freshwater Prawn and other shrimp; $14.45 \%$ fished Giant Freshwater Prawn, other shrimps and mud crab; and the rest, 21.46\%, fished Giant Freshwater Prawn, other shrimps, fish and crab in the SME.

Out of eight gears surveyed in the present study, the percentage of hook-line was $19.33 \%$ (Table 2). The average number of hook-line per boat was found to be $6.17 \pm 2.19$ (49). The estimated average length, total length and bait gap/gear gap in meter were 268.36 \pm 20.96 (196-298), $1105.11 \pm 29.96$ (1191-1621) and 0.46 \pm 0.36 (0.21-1.0), respectively. The number of hook-line fisher per boat varied from 1 to 2 . The life of hook-line was found to be one year. Five types of bait were used with the hook-line. The maximum $(70.91 \%)$ fishers was found to use eel as bait followed by earthworm (13.64\%), shrimp (7.27\%), snakehead (Taki, Channaorientalis, 5.23\%), and skates (2.95\%).

The number of secondary gears used in catching Giant Freshwater Prawn as nontarget species was found to be seven- i) Badhajal; ii) Gill net; iii) KhalPata; iv) Charpata; v) Chandijal; vi) Kathijal; and, vii) Setbagnet/Behundijal. Among these, the maximum frequency was found for Chandijal $(21.08 \%)$ followed by the gill net $(11.83 \%)$, Setbagnet/Behundijal (11.76\%), Badhajal (8.12\%) and Charpata (11.34\%) (Table 3). 
The number of fishers per boat was found to be dependent on the function of gear type, number and size. For example, minimum six persons are required to operate Charpata or Kathijal, whereas two fishers are enough for operating Setbagnet or Behundijal and one person for the Hookline. However, for ensuring security, a minimum of two fishing on a boat enter into the Sundarbans. Moreover, the number or length of gear depends on the financial capacity of the fishers/operators. No baited gears are used as secondary gear for Giant Freshwater Prawn fishing. Most of the secondary gears were found to be made of nylon or cotton twinges, operate in the river in all seasons in the SME.

\section{Crafts Used in Giant Freshwater Prawn Fishing}

The artisanal fishery in the Sundarbans absolutely relies on non-mechanized boats operated by manual oars (Boithya) or sail (Paal) operated by the fishers. Four different types of wooden boats namely, small Balam, small boat, small Dingi and large Nouka were found to operate in the Giant Freshwater Prawn fishery in the SME (Table 4). The length and width of these boats were found to vary from 6.0 to $13.25 \mathrm{~m}$ and 1.0 to $3.2 \mathrm{~m}$, respectively.

The Balam boat is locally called the 'Behundijal Nouka' which is primarily used in operating the Behundijal (setbagnet). However, it is used for operating other gears too, such as - Badhajal, Charpata, Chandijal, Gill nets and Longline (Borshi) within the SME of Bangladesh. Small Balam boats vary from 7.5-8.5 m in length, 1.5-2.0 m in breadth and 0.7$0.8 \mathrm{~m}$ in depth. It is made with the mixture of several types of locally available woods such as Chambol, Gewa (Excoecariaagallocha), Jackfruit (Artocarpusheterophyllus), Jamrul(Lagerstroemia sp.) etc. The bottom of the boat is round. A pair of wood made oars is used to manipulate the boat. The boat is handled by one to two persons. The carrying capacity of the boat ranges from 800 to $1000 \mathrm{~kg}$.; nine feet long hoods, made of bamboo sticks, to the posterior part of the boat, is used under the hood. The fishermen use the platform (floor) under the hood for cooking and taking rest.

The small boat is locally called 'CharjalNowka' or 'ChotoNowka'. It is employed for operating a variety of gears namely, single Charpata, Gill nets, Hookline, Kathijal and Khalpata mainly in the rivers and canal within the SME. It varies from 6.0-6.5 $\mathrm{m}$ in length, $1.0-1.2 \mathrm{~m}$ in breadth and 0.6-07 $\mathrm{m}$ in depth. The bottom of the boat is round. A pair of oar, made of wood, is sufficient to manipulate the boat. The boat is handled by two to three fishermen. The carrying capacity of the boat ranges from 400 to $500 \mathrm{~kg}$. This boat is made of wood from Raintree (Samaneasaman), Khoi, Sunduri (Heritierafomes), Gewa (Excoecariaagallocha), Meglan, Betelnut, etc.

The small Dingi, comparatively smaller in size, is locally called 'Chai Nowka'. It is used for the operation of Setbagnet, Baited hookline, Khalpata and for crab traps (bamboo traps). It is $6.5-7.0 \mathrm{~m}$ in length, $1.2-1.5 \mathrm{~m}$ in breadth and $0.6-0.7 \mathrm{~m}$ in depth with a round bottom. It is made of locally available Chambol, Gewa (Excoecariaagallocha), Jackfruit (Artocarpusheterophyllus), Jamrul (Lagerstroemia sp.), Kewra (Sonnerataspecies), Khoiyababla (Acacia nilotica), Khoi, Koroi (Albizziaprocera), Raintree (Samaneasaman), Badam (Masuaferrea), Sunduri (Heritierafomes), Meglan, and Betelnut wood. The boat is handled by two fishermen. A pair of wooden oar is used to manipulate the boat. The carrying capacity of the boat ranges from 500 to $600 \mathrm{~kg}$.

Large Nouka, locally also known as 'Nau' is comparatively larger with a round bottom and 7.06 $\pm 4.38(8.78-13.25) \mathrm{m}$ in length, $1.58 \pm 1.15(1.03-3.20) \mathrm{m}$ in breadth and 
1.55 $\pm 3.16(0.9-1.7) \mathrm{m}$ in depth. It is used for the operation of Setbagnet, Khalpata, Hilsha gill net, Badhajal, Charpata and Mud crab traps. It is made of locally available woods, namelyChambol, Gewa, Jackfruit, Jamrul, Kewra, Khiyababla, khoi, Koroi, Raintree, Badam, Sunduri, Meglan and Betelnut etc. The boat is handled by two to three fishermen. A pair of wood made oar is used to manipulate the boat. The carrying capacity of this boat ia about 700 to $800 \mathrm{~kg}$.

\section{Timing of Harvesting of Giant Freshwater Prawn Fishing in SME}

\section{Fishing season}

Climatologically, there are four seasons in Bangladesh - pre-monsoon (March-May), monsoon (June- September), post-monsoon (October-November) and the dry winter season (December-February). However, the present study reveals that fishing activity inside the SME varied by target species, and hence, gear type to be employed. Giant Freshwater Prawn fishing with Hookline usually started in Bhadra (August-September) and ended in Chatra (March-April). Boishak (April-May) to Sharabon (July-August) was found to be the offseason for this gear. Three terms are used to define the intensity of catch rate, being the highest as peak fishing season, moderate as the medium fishing season and the poor catch rate as lean fishing season (Table 5). The peak season for Giant Freshwater Prawn fishing in the SME was December, January and February (dry winter season), while the lean season was May-August (one third of pre-monsoon and three fourth of monsoon) was the lean season. The moderate seasons were March-April, September-November (two third of the premonsoon and the post-monsoon). However, Giant Freshwater Prawn is harvested at small quantities as by-catch by the other seven types of non-target gears, except for the Hilsha gill net, round the year along with the targeted whitefish (Latescalcarifer, Pangasiuspangasius, Scatophagusaurgus, Plotosuscanius), and/or penaeid shrimps (Penausindicus, Metapenaeusmonoceros).

The maximum fishing length (days/yr) was found at 305 for the Hookline which was followed by 300 days for Kathijal and Charpata, and 110 days for Charpata. On the other hand, the lowest time (150 days/yr) elapsed was for the Badhajal. There was no fixed length of days for a fishing trip; usually it varied from 5 to 12 days, depending on the catch. However, the number of fishing trip per month was found to be two for all the gears, specifically during lunar spring tide phases. The highest length of peak season was recorded for the Kathijal (143 days/yr) followed by the Charpata (110 days/yr) and Hookline (65 days/yr). While the highest length of lean season was recorded for the Charpata (163 days/yr) followed by the Kathijal (128 days/yr). The length of moderate fishing intensity varied from the minimum 30 days/yr for Kathijal to the maximum 210 days/yr for Chandijal. The length of moderate fishing intensity for the primary Giant Freshwater Prawn fishing gear Hookline was found to be 195 days.

\section{Fishing period by dial and lunar phases}

The time spend for a haul and in a day in fishing were found to be varied primarily by fishing gear, target species and the day of the lunar phase (Table 6). Hauling time varied by gear length and the length of high water pulses of semi-diurnal tides. The maximum number of fishermen $(76.25 \%)$ were found to prefer fishing intensely during the day light period. However, they catch at night during poor catch days in order to ensure returns on investment 
and/or profit. If the catch rate was found poor even at night, they extended fishing days up to 2-5 days in a trip. The average time per haul (hr.) for fishing was found to vary from $4.40 \pm 2.12$ for the Behundijal to $11.33 \pm 2.00$ for the Charpata. For the Hookline, it was $5.67 \pm 0.52$ hours (minimum 5 and maximum 6 hours) per day. Number of haul per day ranged from 1 to 3. The highest mean hauling time (hrs/day) was recorded for Kathijal at 8.75-17.5 hrs/day followed by Behundijal at 8.8-13.2 hrs/day and 11.34 $\pm 1.6 \mathrm{hrs} /$ day for the Hookline fishery. The Charpata required the highest time, $11.33 \pm 4.35 \mathrm{hrs}$ per day for a single haul.

Most of the fishers (63.64\%) in the SME perceived no tidal influence on the catch rate but perceived that poor catch rate during the night time. However, only $18.18 \%$ fishers preferred night-time catching (Table 6). The rest, $18.18 \%$ fishers, perceived that the rate of Giant Freshwater Prawn catch varied by season, being the highest during May-June and August-November, the lowest during January-March and moderate throughout the rest of the months (December- January and April- May). Only the Kathijal and Khalpata were operated during high tide phases. The Hookline for Giant Freshwater Prawn fishing, however, was found to operate irrespective of day/night or low/high tides. Due to the security reason, most of the fishers operate fishing activity in a group. The catching rate was reported independent of lunar phases by most of the fishers (63.64\%) who operate secondary gears, only $36.36 \%$ of fishers reported comparatively higher catches during full moon days. However, for the Hookline fishers, almost all $(100 \%)$ the fishers reported empty catch during the new moon days, i.e. new moon phase is completely unfavorable for Giant Freshwater Prawn fishery with Hookline in the SME. The fishing time preference by the fishermen and catch composition are given in Table 7. Almost all the Hookline fishers (100\%) agreed that day time was not suitable for higher Giant Freshwater Prawn catches.

\section{Hotspot fishing and night staying areas}

Fishers identified 25, 3 and 2 hotspot areas for Giant Freshwater Prawn fishing in the Sharankhola, Chandpai and Khulna ranges, respectively (Table 8). However, in practice they cannot go there regularly due to distances from their homes, volume of credit to be repaid on return, preferences of other fishers in forming a group, etc. About $48.36 \%$ of the fishermen identified Harbaria and Mora Passure as the number one hotspot for higher Giant Freshwater Prawn assemblage. Practically, however, only $28.57 \%$ fishers fish at Herbaria and $5.49 \%$ in Mora Passure areas (Table 9). Another 27.47\% fishers fished in the Meheali area. Meherali was found to be the most secured place to fish over Harbaria or Mora Passure.

Due to the security reason, Giant Freshwater Prawn fishers stay in 11 Forest Petrol stations at night. However, for the night stay, a maximum of $30.77 \%$ fishers preferred Harbaria and the minimum preferred Karamjal (1.1\%). About $18.68 \%$ of fishers preferred Meherali, $21.97 \%$ Kokilmuni and $12.09 \%$ Dubla Island.

\section{Amount of Harvesting of Giant Freshwater Prawn Fishing in SME}

\section{Estimated Production}

Among eight gears operated in the SME, only the Hookline (borshi), is used in catching Giant Freshwater Prawn (Macrobrachiumrosenbergii) as target species. However, it catches other high valued fish such as sea bass (Latescalcarifer), mud crab (Scylla olivacea), 
Indian salmon (Polymenusindicus) etc. as a by-catch. Therefore, results have been presented in two categories- i) by Primary gear (Hook-line) that targeted Giant Freshwater Prawn as the main catch; and ii) secondary gear (gears that catches Giant Freshwater Prawn as a bycatch). Mean daily, seasonal (peak, lean and moderate) and annual catch by different gear (per gear) are presented in Table 10.

The mean daily catch $\left(\mathrm{kg} \mathrm{day}^{-1} \mathrm{gear}^{-1}\right)$ during peak season by a single hookline was estimated at $0.20 \pm 0.21$ (range: $0.09-0.61)\left(\mathrm{kg} \mathrm{day}^{-1} \mathrm{gear}^{-1}\right)$. The highest volume was caught by the Kathijal (mean: 1.06 \pm 0.23 ; range: 0.35-1.47), followed by the Badhajal (mean: 1.05 \pm 0.81 ; range: 0.84-1.46). The Chandijal harvested the lowest catch (mean: $0.13 \pm 0.10$; range: 0.02-0.54) after the Hookline. During the lean season, the daily mean catch of a single Hookline was only $0.12 \pm 0.31$ (range: $0.00-0.17$ ) $\mathrm{kg} \mathrm{day}^{-1}$ gear $^{-1}$ It increased a little (mean: $0.16 \pm 0.97$; Range: $0.10-0.21 \mathrm{~kg} \mathrm{day}^{-1} \mathrm{gear}^{-1}$ ) during the moderate fishing season.

The mean highest daily harvest volume $\left(\mathrm{kg} \mathrm{day}^{-1}\right.$ boat $\left.^{-1}\right)$ was estimated for the Kathijal at $1.00 \pm 0.96$ (range: $0.24-1.17 \mathrm{~kg} \mathrm{day}^{-1}$ boat $^{-1}$ ), followed by the Badhajal at $0.99 \pm 0.27$ (range: 0.26-1.00) and the Hookline at 0.99 \pm 0.42 (range: 0.06-0.33). The highest annual catch per boat was recorded at $172.80 \mathrm{~kg}_{\text {boat }}{ }^{-1} \mathrm{yr}^{-1}$ for the Hookline, followed by $172.24 \mathrm{~kg}$ for the Chandijal, $157.73 \mathrm{~kg}$ for the Behundijal and the lowest $152.08 \mathrm{~kg}$ for the Khalpatajal.

The variation in catch rates between seasons and gears are probably due to the variation in gear number/boat and fishing day length for different gears. The mean highest number of gear per boat was recorded at 10.00 \pm 3.65 individuals (range: 6.00-14.00) for the Chandijal fishery followed by $6.17 \pm 2.19$ individuals (range: 4.00-9.00) for the Hookline.

The pooled seasonal catches per gear $\left(\mathrm{kg} \mathrm{day}^{-1} \mathrm{gear}^{-1}\right)$ by all seven gears surveyed were estimated at $4.27 \mathrm{~kg}$ for peak season, $3.14 \mathrm{~kg}$ for lean season and $3.67 \mathrm{~kg}$ for moderate season. The annual daily catch rate/gear was $7.56 \mathrm{~kg} \mathrm{day}^{-1} \mathrm{gear}^{-1}$; while total annual catch was estimated to be by all the gears at 1,318.60 kg from 1,428 gears, 545 boats and 1,989 fishers.

\section{Estimated CPUE}

The catch per unit effort (CPUE, kg/boat) per day, per trip, per season and per year by eight different gears is presented in Table 11. The mean daily catch rate of Hookline was estimated at $0.99 \pm 0.25 \mathrm{~kg}_{\text {boat }}{ }^{-1} \mathrm{day}^{-1}$. It was $1.24 \pm 1.20,0.75 \pm 0.65$ and $0.99 \pm 0.98 \mathrm{~kg}_{\text {boat }}{ }^{-1}$ day $^{-1}$ for peak season (full dry winter season), lean season (one third of pre-monsoon and three fourth of monsoon) and moderate season (two third of the pre-monsoon and full of the postmonsoon) respectively. Significantly, highest mean daily catch per boat $(1.00 \pm 0.06 \mathrm{~kg})$ was obtained from the Kathijal followed by the Badhajal $(0.99 \pm 0.0606 \mathrm{~kg})$. However, the highest daily catch per day was the highest for Candijal $(1.29 \pm 0.76 \mathrm{~kg})$ during peak season, Kathijal $(0.95 \pm 1.02 \mathrm{~kg})$ during lean season and Badhajal $(1.00 \pm 1.25 \mathrm{~kg})$ during moderate season. The catch rate of Hookline was the second $\left(1.24 \pm 1.20 \mathrm{~kg}^{\text {boat }}{ }^{-1}\right.$ day $\left.^{-1}\right)$, during the peak season; fourth $\left(0.75 \pm 0.65 \mathrm{~kg}_{\text {boat }}{ }^{-1} \mathrm{day}^{-1}\right)$ during the lean season and second $\left(0.99 \pm 0.98 \mathrm{~kg}_{\text {boat }}{ }^{-1}\right.$ day $^{-1}$ ) during the moderate season.

No significant variation $(\mathrm{P}<0.05)$ was observed in the mean catch rate per trip boat ${ }^{-1}$ among the gears studied with the highest catch rate from the Kathijal $(7.01 \pm 0.39 \mathrm{~kg})$ and the lowest from the Khalpata $(5.87 \pm 2.14 \mathrm{~kg})$. The Hookline catch rate at $6.94 \pm 1.65 \mathrm{~kg}$ was very 
close to the catch rate from of the Behundijal $(6.95 \pm 0.39 \mathrm{~kg})$, Setbagnet/behundijal $(6.48 \pm 0.56 \mathrm{~kg})$, Charpata $(6.37 \pm 2.61 \mathrm{~kg})$, Chandiljal $(6.71 \pm 2.14 \mathrm{~kg})$ and Gill net $(6.59 \pm 1.60$ $\mathrm{kg})$. Variation in catch rate $\left(\mathrm{kg}\right.$ trip $^{-1}$ boat $\left.^{-1}\right)$ by Hookline was insignificant, being the highest $8.67 \pm 1.65 \mathrm{~kg}$ during peak season, $6.94 \pm 1.65$ during moderate season and $5.22 \pm 2.11 \mathrm{~kg}$ during lean season. During the peak (full dry winter season), lean (one third of pre-monsoon and three fourth of monsoon) and moderate season (two third of the pre-monsoon and full of the post-monsoon) per boat per trip catch was recorded at $9.04 \pm 4.12 \mathrm{~kg}, 6.66 \pm 3.12 \mathrm{~kg}$ and $6.98 \pm 2.14 \mathrm{~kg}$ for the Chandijal, Kathijal and Badhajal, respectively.

However, volume of mean catch rate per boat (seasonal catch volume, $\mathrm{Kg}$ ) during peak, moderate and lean fishing season by the Hookline was estimated to be $106.51 \pm 26.35$ $\mathrm{kg}, 48.43 \pm 17.21 \mathrm{~kg}$ and $16.86 \pm 4.11 \mathrm{~kg}$, respectively. The highest catch per boat during peak, lean and moderate season was estimated for the Chandijal $(111.09 \pm 15.36 \mathrm{~kg})$, Badhajal $(16.95 \pm 8.12 \mathrm{~kg})$, and Kathijal $(61.87 \pm 24.22 \mathrm{~kg})$, respectively. The lowest catch was recorded for the Khalpata at $13.12 \pm 6.32 \mathrm{~kg}$. The annual catch rate per boat was estimated at $172.82 \mathrm{~kg}$ for the Hookline, $172.24 \mathrm{~kg}$ for the Chandijal, $171.06 \mathrm{~kg}$ for the Kathijal, $168.88 \mathrm{~kg}$ for the Badhajal, $166.89 \mathrm{~kg}$ for the Gill net, $157.73 \mathrm{~kg}$ for the Setbagnet and $156.89 \mathrm{~kg}$ for the Charpata.

The mean daily CPUE by fisher ( $\mathrm{kg}$ /day/fisher) for the Hookline was estimated at $0.62 \mathrm{~kg}, 0.50 \mathrm{~kg}$ and $0.37 \mathrm{~kg}$ during peak, moderate and lean fishing seasons respectively. While the mean daily CPUE by boat (kg/day/boat) was found to be $4.08 \mathrm{~kg}, 1.62 \mathrm{~kg}$ and 1.08 $\mathrm{kg}$ during peak, moderate and lean season, respectively. The annual CPUE by per fisher per boat (total season) was the highest for Badhajal $(0.50 \pm 0.03 \mathrm{~kg})$ followed by Hookline $(0.50 \pm 0.12 \mathrm{~kg})$. The annual CPUE for Setbagnet/behundijal, charpata, chandijal, gill net, kathijal and khalpata was estimated at $0.46 \pm 0.04,0.26 \pm 0.11,0.16 \pm 0.05,0.24 \pm 0.06$, and $0.17 \pm 0.01$ and $0.28 \pm 0.10 \mathrm{~kg}$, respectively.

\section{Conclusion and Recommendation}

The study conducted to focus the efficiency of gears for harvesting small-scale artisanal Giant Freshwater Prawn fishery in the SME of Bangladesh. Four types of non-mechanized crafts and eight types of gears used for harvesting Giant Freshwater Prawn. The Hookline has been found as the single primary active gear for Giant Freshwater Prawn fishing. The rest of the other gears are multi-species and harvests Giant Freshwater Prawn as a by-catch. Only $13.60 \%$ of fishers use Hookline, rest of the $86.4 \%$ fishers use the seven other gears and $3.24 \%$ of their total catch is Giant Freshwater Prawn harvested as a by-catch. The highest daily harvest volume per boat $\left(\mathrm{kg} \mathrm{day}^{-1}\right.$ boat $\left.^{-1}\right)$ is $1.00 \pm 0.96$ for Kathijal, followed by $0.99 \pm 0.27 \mathrm{~kg}$ for the Badhajal and $0.99 \pm 0.42 \mathrm{~kg}$ for the Hookline. The highest annual catch per boat $\left(\mathrm{kg}\right.$ boat $\left.{ }^{-1} \mathrm{yr}^{-1}\right)$ was $172.80 \pm 0.29 \mathrm{~kg}$ for the Hookline followed by $172.24 \pm 0.54 \mathrm{~kg}$ for the Chandijal and it was the lowest, $152.08 \pm 0.21$, for the Khalpata.

The Department of Forest is the legal authority in the management of aquatic resources inside the waters of the SME of Bangladesh. The authority should care about the sustainable management of small-scale fisheries to ensure a sustainable growth rate of Giant Freshwater Prawn, and protect over exploitation. At the same time, the authority must care about the inefficient method of fishing that harms other species, such as the set bagnet where the fishers catch a considerable volume of juveniles and sub-adults of numerous shrimps and fish species as a by-catch. Some fishers used long gill and seine nets of $1.5-2.5 \mathrm{~cm}$ mesh during November-April, and made severe damage to migratory juvenile Jatka (Hilsha) 
throughout the Sundarbans. On the other hand, shore seine and canal gillnet fisheries in the inshore area block long areas of the shore and the mouths of small canals. These gears are capable of catching virtually all fishes (juvenile/adults). The set bagnet and pull and push nets for shrimp post larvae in the inshore area, rivers and canals, also catch enormous numbers of eggs, larvae and fry of many fishes, shrimps, prawn, crabs, and mollusks. Sharks, sawfish and stingrays are also caught by a number of gears. Therefore, to achieve a sustainable management of the Giant Freshwater Prawn fishery and conserving the habitat and flora and fauna in SME, the forest department needs to take proper initiatives and should focus mostly on the Hookline gear usage for harvesting and increase awareness among fishers to not harm other species.

\section{Acknowledgement}

We are thankful to the The Fisheries and Marine Resource Technology Discipline, Khulna University for their assistance in conducting the research. We would also like to thank Professor Dr. KhandakarAnisulHoq, Professor Dipak Kamal, Mr.Nurul Islam and Mr.Bipul Kumar Nondi for their advice and support at various stages of the study. This research is partially supported by the grants UKM-AP-2011-23 and LRGS 203/PKT/6720004 (Programme 203/PKT/6724003).

\section{References}

Aftabuzzaman, 1998. Sustainable Environment - Friendly Aqua-culture. In Centre for Policy Dialogue, Environmental Consequences of Export Oriented Shrimp Culture in Bangladesh, CPD Dialogue Report No. 18, Centre for Policy Dialogue, Dhaka, Bangladesh. 78.

Ahmed, N., 2001. Socio-Economic Aspects of Freshwater Prawn Culture Development in Bangladesh.PhD thesis, University of Stirling, UK. 256.

Ahmed, N., 2002. Socio-economic aspects of freshwater prawn culture development in Mymensingh, Bangladesh. International Center for Living Aquatic Resources Management (ICLARM) Report. Dhaka, Bangladesh. 118-122.

Ahmed, N.; Ahammed, F. and Brakel, M.V., 2008. An Economic Analysis of Freshwater Prawn, Macrobrachiumrosenbergii, Farming in Mymensingh, Bangladesh. Journal of the World Aquaculture Society, 39(1): 37-50.

Alam, S.M.N.; Pokrant, B.; Yakupitiyage, A. and Phillips, M.J., 2007. Economic returns of disease-affected extensive shrimp farming in southwest Bangladesh, Aquacult Int. 15:363-370.

Ali, M.Y.; Kamal, D.; Hossain, S.M.M.; Azam, M.A.; Sabbir, W.; Murshida, A.; Ahmed, B. and Azam, K., 2004.Biological Studies of the Mud Crab, Scylla serrata(Forskal) of the Sundarbans Mangrove Ecosystem in Khulna Region of Bangladesh. Pakistan Journal of Biological Sciences 7 (11): 1981-1987.

BBS, 2005. "Statistical Yearbook of Bangladesh; 2005", Bangladesh Bureau of Statistics, Statistics Division, Ministry of Planning, Government of the People's Republic of Bangladesh, Dhaka, Bangladesh.

BCAS, 2001.The costs and benefits of bagda shrimp farming in Bangladesh - an economic, financial and livelihoods assessment. Prepared as part of the Fourth Fisheries Project by Bangladesh Centre for Advanced Studies. August 2001.

Bernacsek, G., 2001. Catalogue of fishing gears of the Sundarbans and marine zone. Draft report. Sundarbans biodiversity conservation project, Aquatic resources programme, Khulna, Bangladesh

Bhattacharya, D.; Rahman, M. and Khatun, F.A., 1999a. Environmental Impact of Trade Liberalization and Policies for the Sustainable Management of Natural Resources: A 
Case Study on Bangladesh's Shrimp Farming Industry, Centre for Policy Dialogue (CPD), Dhaka, Bangladesh.

Bhattacharya, D.; Rahman, M. and Khatun, F.A., 1999b. Environmental Impact of Structural Adjustment Policies: The Case of Export Oriented Shrimp Culture in Bangladesh. (CPD), Dhaka, Bangladesh.

BOBP, 1994. "Biosocioeconomic Assessment of the Effect of the Estuarine SetBagnet on the Marine Fisheries of Bangladesh”; Bay of Bengal Programme (BOBP), Madras, India.

BOBP, 1996. "Towards Sustainability: Needs and Concerns of Aquatic Resources and Fisheries in the Bay of Bengal Region and Project Ideas to Facilitate Their Sustainable Management", Madras, India.

Chantarasri, S., 1994. Fisheries resources management for the Sundarbans reserved forest. In: Integrated resource development of the Sundarbans reserved forest, Bangladesh (BGD/84/056), Fourth draft final report. Khulna, Bangladesh: FAO/UNDP, 1994, $171 \mathrm{pp}$.

Chaudhuri, A.B. and Choudhury, A., 1994. Mangroves of the Sundarbans.Vol. 1, India.IUCN, Bangkok, Thailand.

Chowdhury, Z.A.; Khan, M.G. and Quayum, S.A., 1993.The Beach Seine Fishery of Teknaf. p. 51-64. In: Studies of interactive marine fisheries of Bangladesh. Bay of Bengal Program, BOBP/WP/89.

DoF (Department of Fisheries), 2008a. Fish Catch Statistics of Bangladesh, Bangladesh Fishery Resources Survey System.BFRSS, Department of Fisheries, Dhaka, Bangladesh.

DoF (Department of Fisheries), 2008b. Fishery Statistical Yearbook of Bangladesh 20062007.Fisheries Resources Service System, Department of Fisheries (DOF), Ministry of Fisheries and Livestock, Dhaka, Bangladesh, 42.

DoF (Department of Fisheries), 1982. Fisheries week 1982.Souvenir.Department of Fisheries, Fisheries and Livestock Department.Dhaka.

DoF (Department of Fisheries), 1983. Fish Catch Statistics of Bangladesh, Bangladesh Fishery Resources Survey System.BFRSS, Department of Fisheries, Dhaka, Bangladesh.

DoF (Department of Fisheries), 1991. Fish Catch Statistics of Bangladesh, Bangladesh Fishery Resources Survey System.BFRSS, Department of Fisheries, Dhaka, Bangladesh.

DoF (Department of Fisheries), 1992. Fish Catch Statistics of Bangladesh, Bangladesh Fishery Resources Survey System.BFRSS, Department of Fisheries, Dhaka, Bangladesh.

DoF (Department of Fisheries), 2005. Fish Catch Statistics of Bangladesh, Bangladesh Fishery Resources Survey System.BFRSS, Department of Fisheries, Dhaka, Bangladesh.

DoF (Department of Fisheries), 2006. Fish Catch Statistics of Bangladesh, Bangladesh Fishery Resources Survey System.BFRSS, Department of Fisheries, Dhaka, Bangladesh.

FAO, 2003.Globefish Commodity Update: Shrimp. Food and Agriculture Organization of the United Nations. June 2003.

Gain,P., 1998.Bangladesh Environment: Facing the 21st Century.

Giasuddin, M.K. $(E d), 2002$. Review of the current knowledge on coastal shrimp fry collection and it's impact on biodiversity. Fourth Fisheries Project report -2002 onPL Fishery Management Action Plan,Department of Fisheries, Ministry of Fisheries \& Livestock, Dhaka, Bangladesh, , supported by Global Environment Facility/World Bank under Aquatic Resources Development, Management and Conservation Studies 
Giri, C. and Shrestha, S., 1996. Land cover mapping and monitoring from NOAA AVHRR data in Bangladesh. International Journal of Remote Sensing, 17 (14): 2749-2759.

Guha, Bakshi, D.N., Sanyal, P. and Naskar, K.R. (Eds.), 1999.SundarbansMangal.NayaProkash, Calcutta, $771 \mathrm{pp}$.

Haggan, N.; Brignall, C. and Wood, L. (eds), 2003. Putting Fishers' Knowledge to Work. FCRR 2003, Vol. 11(1): 433-438. Proceedings of a conference held at the Fisheries Centre, University of British Columbia during August 27-30, 2001.

Halim, S.; Hoq, M.E.; Kamal, M. and Wahab, M.A.,2001.Feasibility study for the shrimp component of the Fourth Fisheries Project: Women and children study. Prepared by Bangladesh Centre for Advanced Studies, Dhaka, July 2001.

Haque, 1995. How fishers' endeavors and information help in managing the fisheries resources of the sundarban mangrove forest of bangladesh. In fisheries management in the sundarban mangroves, bangladesh. Department of Forest, Bangladesh, $433 \mathrm{pp}$.

Haque, M.E., 2003. How fishers' endeavors and information help in managing the fisheries resources of the Sundarban mangrove forest of Bangladesh, University of British Columbia, Fisheries Center Research Report 11(1):433-438.

Haque, Q.M.; Khan, M.G.; Chowdhury, Z.A. and Sarker, M.N., 1993b.The Bottom Longline Fishery for Croaker (Sciaenidae). p. 107-117. In Studies of interactive marine fisheries of Bangladesh. BOBP/WP/89.

Hoq, M.E., 2007. An analysis of fisheries exploitation and management practices in Sundarbans mangrove ecosystem, Bangladesh. Ocean \& Coastal Management, 50: 411-427.

Hoq, M.E.; Islam M.N.; Kamal, M. and Wahab, M.A., 2001.Abundance and seasonal distribution of Penaeusmonodonpostlarvae in the Sundarbans mangrove, Bangladesh.Hydrobiologia, 457: 97-104.

Hoq, M.E.;Islam, M.N.; Kamal, M. and Wahab, M.A., 2003. Fisheries structure and management implications in Sundarbans mangrove reserved forest, Bangladesh. Indian Journal of Fisheries, 50(2): 243-249.

Hoq, M.E.; Wahab, M.A. and Islam, M.N., 2006. Hydrographic status of Sundarbans mangrove, Bangladesh with special reference to post-larvae and juveniles fish and shrimp abundance. Wetlands Ecology and Management, 14: 79-93.

Hossain, M.N. and Ahmed, A.T.A., 2006. Crafts and gears used in catching mud crab, Scylla olivacea (Herbst) in Bangladesh. J. Asiat. Soc. Bangladesh, Sci., (32)1: 1-10.

Hussain, Z. and Acharya, G. (Eds.), 1994.Mangroves of the Sundarbans.Volume 2: Bangladesh. World Conservation Union, Gland, $257 \mathrm{p}$.

Islam, M.N. (Ed.), 2007. Annual Report, 2005-2006. Department of Fisheries, Ministry of Fisheries \& Livestock, Dhaka, Bangladesh, pp. 32-34.

Islam, M.S., 2003. Perspectives of the coastal and marine fisheries of the Bay of Bengal, Bangladesh. Ocean \& Coastal Management, 46: 763-796.

Islam, M.S. and Haque, M., 2004. The mangrove-based coastal and nearshore fisheries of Bangladesh: ecology, exploitation and management. Reviews in Fish Biology and Fisheries, 14: 153-180.

Islam, M.S. and Wahab, M.A., 2005. A review on the present status and management of mangrove wetland habitat resources in Bangladesh with emphasis on mangrove fisheries and aquaculture.Hydrobiologia, 542: 165-190.

Khan, M.G., 1983. Results of the 13th Cruise (July, 1983) with the R.V. Anusandhani of the demersal fish and shrimp ground of the Bay of Bengal, Bangladesh. Marine Fisheries Survey, Management and Development Project, GOB, Chittagong.

Manju., 1996; NijeraKori, 1996; cited in/summarised by UNEP. 1999. Environmental Impacts of Trade Liberalization and Policies for the Sustainable Management of 
Natural Resources: A Case Study on Bangladesh's Shrimp Farming Industry. United Nations Environment Programme, New York and Geneva, 1999.

Naskar, K.R. and Guhabakshi, D.N., 1987. Mangrove Swamps of the Sundarbans - An Ecological Perspective.NayaProkash, Calcutta, 263 p.

Quddus, A.H.G.; Rutherford, S. and Phillips, M., 2001.Final Report on Livelihood Analysis under Shrimp Sector.Social Feasibility Studies of the Fourth Fisheries Project.

Rahman, M.M.; Chowdhury, Z.A. and Sada, M.N.U., 2003.Coastal resources management, policy and planning in Bangladesh, pp. 689-756.In: G. Silvestre, L. Garces, I. Stobutzki, M. Ahmed, R.A. Valmonte-Santos, C. Luna, L. Lachica-Aliño, P. Munro, V. Christensen and D. Pauly (Eds.) Assessment, Management and Future Directions for Coastal Fisheries in Asian Countries. WorldFishCenter Conference Proceeding, 67: $1-120$.

Rollet, B., 1981. Bibliography on Mangrove Research 1600-1975. UNESCO, Paris, 479 pp.

Rutherford, S., 1994.CARE and Gher: Financing the Small Fry. Report prepared for CARE International in Bangladesh with support from the Bangladesh Aquaculture and Fisheries Resource Unit (BAFRU).

Seidensticker, J., Kurin, R. and Townsend, A.K. (Eds.), 1991. The Commons in South Asia: Societal Pressures and Environmental Integrity in the Sundarbans. The International Center, Smithsonian Institution, Washington, D.C.

Shah, W.A.; Phillips, M.; Kamal, S.; Jahan, I. and Sarker, J., 2000.The Economics of Bagda Shrimp (PenaeusMonodon) Farming in Coastal Areas of Bangladesh.In:Sen S (Ed.), Grassroots Voice Volume-III, (Issues I \& II), Bangladesh Resource Centre for Indigenous Knowledge, Dhaka, Bangladesh.

Shang, Y.C.; Leung, P.S. and Ling, B.H., 2001.Comparative Economics of Shrimp Farming in Asia.In: Leung P.S. and Sharma K.K. (Eds.), Economic and Management of Shrimp and Carp Farming in Asia. Network of Aquaculture Centres in Asia-Pacific, Bangkok, Thailand.

Thomas, M.A.; Macfadyen, G. and Chowdhury, S., 2001. The costs and Benefits of Bagda Shrimp Farming in Bangladesh.Bangladesh Centre for Advanced Studies, Dhaka, Bangladesh.

UNEP, 1999.Environmental Impacts of Trade Liberalization and Policies for the Sustainable Management of Natural Resources: A Case Study on Bangladesh's Shrimp Farming Industry. United Nations Environment Programme, New York and Geneva.

Vannuccini, S., 1999.The Bangladeshi Shrimp Industry. URL: http://www.fao.org/fi/globe/ blogfish/fishery/globefi/doc/presenta/bangle.

Viju, I.C. 1995. Issues in the management of the environment and natural resources in Bangladesh. Journal of Environmental Management, 45 (4): 319-332.

White, T.F. and Khan, M.G., 1985. The marine fishery resources of Bangladesh and their potential for commercial development. Key note Paper Presented at the National Seminar on Fisheries Development in Bangladesh, Dhaka, January, Souvenir, 1985, pp. 1-4.

Willams, D., 2003. Freshwater prawn farming in Bangladesh.Fish Farmer, 26(5): 24-27. 


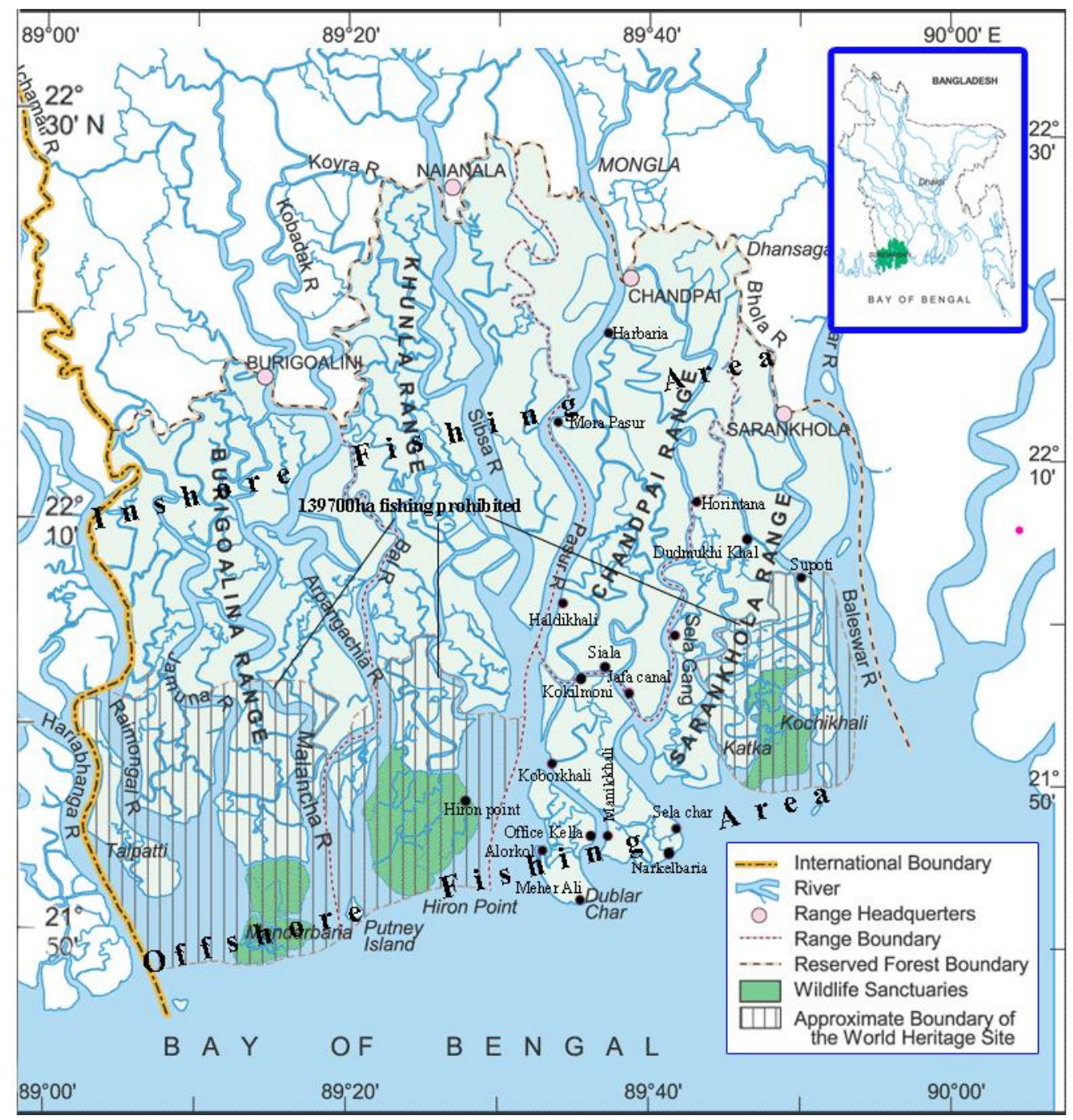

Figure 1: Map of Sundarbans, showing inshore and offshore fishing areas, river systems, world heritage site, wildlife sanctuary and no take areas. Pink mark indicates the present study area. 
Table 1: The GPS locations of the survey areas in the SME

\begin{tabular}{llll}
\hline N Latitude & E Longitude & N Latitude & E Longitude \\
\hline $21^{\circ} 17^{\prime} 08.8^{\prime \prime}$ & $89^{\circ} 34^{\prime} 22.6^{\prime \prime}$ & $21^{\circ} 55^{\prime} 090^{\prime \prime}$ & $89^{\circ} 33^{\prime} 897^{\prime \prime}$ \\
$21^{\circ} 17^{\prime} 11.6^{\prime \prime}$ & $89^{\circ} 38^{\prime} 52.0^{\prime \prime}$ & $21^{\circ} 56^{\prime} 44.4^{\prime \prime}$ & $89^{\circ} 34^{\prime} 59.5^{\prime \prime}$ \\
$21^{\circ} 44^{\prime} 78.4^{\prime \prime}$ & $89^{\circ} 33^{\prime} 27.6^{\prime \prime}$ & $22^{\circ} 14^{\prime} 90.7^{\prime \prime}$ & $89^{\circ} 36^{\prime} 32.4^{\prime \prime}$ \\
$21^{\circ} 45^{\prime} 15.0^{\prime \prime}$ & $89^{\circ} 32^{\prime} 51.8^{\prime \prime}$ & $22^{\circ} 37^{\prime} 11.6^{\prime \prime}$ & $89^{\circ} 29^{\prime} 96.7^{\prime \prime}$ \\
$21^{\circ} 46^{\prime} 09.8^{\prime \prime}$ & $89^{\circ} 32^{\prime} 52.2^{\prime \prime}$ & & \\
\hline
\end{tabular}

Table 2: The number of fishers and gears per boat used in Giant Freshwater Prawn fishing among the respondents

\begin{tabular}{lcccccc}
\hline \multicolumn{1}{c}{ Name of gear } & $\begin{array}{c}\text { Respondent } \\
\text { fishers (n) }\end{array}$ & $\begin{array}{c}\text { Respondent } \\
\text { fishers (\%) }\end{array}$ & $\begin{array}{c}\text { Boat } \\
\text { surveyed } \\
\text { (n) }\end{array}$ & $\begin{array}{c}\text { Gear } \\
\text { surveyed } \\
\text { (n) }\end{array}$ & $\begin{array}{c}\text { Mean } \pm \text { SD } \\
\text { (Min.-Max.) }\end{array}$ & $\begin{array}{c}\text { per boat } \\
\text { (indv.) }\end{array}$ \\
\hline Setbagnet/ Behundijal(B) & 252 & 11.76 & 84 & 168 & $2.00 \pm 0.82(1-3)$ & $1-4$ \\
Badhajal(BJ) & 232 & 8.12 & 116 & 116 & $1.00 \pm 0.00(1-1)$ & 2 \\
Charpata (C) & 265 & 11.34 & 66 & 162 & $2.44 \pm 0.52(2-3)$ & $2-5$ \\
Chandijal (CJ) & 211 & 21.08 & 30 & 301 & $10.00 \pm 3.65(6-14)$ & $6-8$ \\
Gillnet (G) & 135 & 11.83 & 34 & 169 & $5.00 \pm 1.83(3-7)$ & 4 \\
Hookline (H) & 67 & 19.33 & 45 & 276 & $6.17 \pm 2.19(4-9)$ & $1-2$ \\
Kathijal (K) & 630 & 7.35 & 105 & 105 & $1.00 \pm 0.00(1-1)$ & $6-8$ \\
KhalPata (KP) & 197 & 9.17 & 66 & 131 & $2.00 \pm 0.82(1-3)$ & 3 \\
\hline Total & 1,989 & 100.00 & 545 & 1,428 & & \\
\hline
\end{tabular}


Table 3: Length, width, mesh size and economic life of different gears used in Giant Freshwater Prawn fishing as non-target species in the Sundarbans

\begin{tabular}{|c|c|c|c|c|c|c|}
\hline Gear name & $\begin{array}{c}\text { Indv. gear length } \\
\text { (GL, m ) } \\
\text { Mean } \pm \text { SD } \\
\text { (Min.-Max.) }\end{array}$ & $\begin{array}{c}\text { Gear } \\
\text { no/ } \\
\text { boat }\end{array}$ & $\begin{array}{l}\text { Total gear length } \\
\qquad(\mathrm{TGL}, \mathrm{m}) \\
\text { Mean } \pm \text { SD } \\
\text { (Min.-Max.) }\end{array}$ & $\begin{array}{c}\text { Gear width } \\
(\mathrm{GW}, \mathrm{m}) \\
\text { Mean } \pm \text { SD } \\
\text { (Min.-Max.) }\end{array}$ & $\begin{array}{c}\text { Gear mesh size } \\
\qquad(\mathrm{MS}, \mathrm{cm}) \\
\text { Mean } \pm \text { SD } \\
\text { (Min.-Max.) }\end{array}$ & $\begin{array}{c}\text { Gear life (yr) } \\
\text { Mean } \pm \text { SD } \\
\text { (Min.-Max.) }\end{array}$ \\
\hline Behun & $\begin{array}{l}26.10 \pm 14.71 \\
(7.32-61.72)\end{array}$ & 2.00 & $\begin{array}{c}56.33 \pm 40.33 \\
(14.64-132.60)\end{array}$ & $\begin{array}{c}11.42 \pm 9.33 \\
(0.0-32)\end{array}$ & $\begin{array}{l}2.15 \pm 1.60 \\
(0.76-6.0)\end{array}$ & $\begin{array}{c}2.20 \pm 0.88 \\
(1-4)\end{array}$ \\
\hline Badhajal & $\begin{array}{l}22.86 \pm 16.84 \\
(22.86-22.86)\end{array}$ & 1.00 & $\begin{array}{c}22.86 \pm 42.46 \\
(22.86-22.86)\end{array}$ & $\begin{array}{c}15.20 \pm 11.46 \\
(15.20-15.20)\end{array}$ & $\begin{array}{l}3.16 \pm 3.72 \\
(0.81-9.50)\end{array}$ & $\begin{array}{c}2.00 \pm 0.63 \\
(2-3)\end{array}$ \\
\hline Charpata & $\begin{array}{l}427.63 \pm 246.89 \\
(91.44-777.24)\end{array}$ & 2.44 & $\begin{array}{c}862.45 \pm 463.60 \\
(365.76-1644.00)\end{array}$ & $\begin{array}{l}4.47 \pm 0.53 \\
(3.66-5.03)\end{array}$ & $\begin{array}{l}2.67 \pm 0.70 \\
(1.00-5.00)\end{array}$ & $\begin{array}{c}2.00 \pm 0.33 \\
(0.5-1)\end{array}$ \\
\hline Chandijal & $\begin{array}{c}2194.56 \pm 19.96 \\
(2194.56-2194.56)\end{array}$ & 10.00 & $\begin{array}{c}21945.60 \pm 45.59 \\
(21945.6-21945.6)\end{array}$ & $\begin{array}{l}9.14 \pm 14.58 \\
(9.14-9.14)\end{array}$ & $\begin{array}{c}7.58 \pm 6.85 \\
(5.00-10.16)\end{array}$ & $\begin{array}{c}1.00 \pm 0.43 \\
(0.3-2)\end{array}$ \\
\hline Gillnet & $\begin{array}{c}228.60 \pm 17.83 \\
(228.60-228.60)\end{array}$ & 5.00 & $\begin{array}{c}1143.00 \pm 43.46 \\
(1143.00-1143.00)\end{array}$ & $\begin{array}{l}3.20 \pm 12.45 \\
(3.20-3.20)\end{array}$ & $\begin{array}{c}6.35 \pm 4.72 \\
(2.54-10.15)\end{array}$ & $\begin{array}{c}2.00 \pm 0.53 \\
(0.75-1)\end{array}$ \\
\hline Kathijal & $\begin{array}{l}71.44 \pm 23.09 \\
(20.57-91.44)\end{array}$ & 1.00 & $\begin{array}{c}71.44 \pm 48.71 \\
(20.57-91.44)\end{array}$ & $\begin{array}{l}7.78 \pm 17.70 \\
(4.57-10.06)\end{array}$ & $\begin{array}{l}3.53 \pm 9.98 \\
(0.50-7.40)\end{array}$ & $\begin{array}{c}2.00 \pm 0.00 \\
(2-2)\end{array}$ \\
\hline KhalPata & $\begin{array}{c}86.58 \pm 24.08 \\
(21.95-151.20)\end{array}$ & 2.00 & $\begin{array}{l}173.15 \pm 182.79 \\
(43.90-302.40)\end{array}$ & $\begin{array}{c}6.17 \pm 0.98 \\
(5.48-6.86)\end{array}$ & $\begin{array}{c}1.50 \pm 2.47 \\
(1.50-3.50)\end{array}$ & $\begin{array}{c}1.50 \pm 0.71 \\
(1-2)\end{array}$ \\
\hline
\end{tabular}

Table 4: The mean length, breadth, depth, and economic life of the boats used in Giant Freshwater Prawn fishing

\begin{tabular}{cccccc}
\hline \multirow{3}{*}{ Boat name } & $\begin{array}{c}\text { Length }(\mathrm{m}) \\
\text { Mean } \pm \text { SD } \\
\text { (Min.-Max.) }\end{array}$ & $\begin{array}{c}\text { Breadth }(\mathrm{m}) \\
\text { Mean } \pm \text { SD } \\
\text { (Min.-Max.) }\end{array}$ & $\begin{array}{c}\text { Depth (m) } \\
\text { Mean } \pm \text { SD } \\
\text { (Min.-Max.) }\end{array}$ & $\begin{array}{c}\text { Carrying } \\
\text { capacity } \\
(\mathrm{mt})\end{array}$ & $\begin{array}{c}\text { Economic life } \\
\text { (yrs.) } \\
\text { Mean } \pm S D \\
\text { (Min.-Max.) }\end{array}$ \\
\hline \multirow{2}{*}{ Small Balam } & $8.2 \pm 0.71$ & $1.75 \pm 0.36$ & $0.75 \pm 0.17$ & $0.80-1.00$ & \\
& $(7.5-8.5)$ & $(1.5-2)$ & $(0.7-0.8)$ & & $10 \pm 2.11$ \\
Small boat & $6.25 \pm 0.35$ & $1.1 \pm 0.14$ & $0.65 \pm 1.07$ & $0.40-0.50$ & $(6$ to 12$)$ \\
& $(6.0-6.5)$ & $(1.0-1.2)$ & $(0.6-07)$ & & \\
Small Dingi & $6.75 \pm 0.35$ & $1.35 \pm 0.22$ & $0.65 \pm 0.07$ & $0.50-0.60$ &
\end{tabular}




$\begin{array}{lcccc}\text { Large Nouka } & 7.06 \pm 4.38 & 1.58 \pm 1.15 & 1.55 \pm 3.16 & 0.70-0.80 \\ & (8.78-13.25) & (1.03-3.20) & (0.9-1.7) & \end{array}$

Table 5: Giant Freshwater Prawn Fishing days (days/yr) in different season and length of trip

\begin{tabular}{|c|c|c|c|c|c|c|}
\hline Gear name & $\begin{array}{l}\text { Peak-season } \\
\text { length } \\
\text { (days/yr) }\end{array}$ & $\begin{array}{l}\text { Lean-season } \\
\text { length(days/yr) }\end{array}$ & $\begin{array}{c}\text { Medium } \\
\text { season length } \\
\text { (days/yr) }\end{array}$ & $\begin{array}{c}\text { Fishing } \\
\text { length(days/yr) }\end{array}$ & $\begin{array}{l}\text { Fishing } \\
\text { intensity } \\
\text { (days/trip) }\end{array}$ & $\begin{array}{c}\text { Fishing } \\
\text { intensity (no } \\
\text { of trips/ } \\
\text { month) }\end{array}$ \\
\hline Behundijal(B) & 60 & 36 & 162 & 258 & 8 & 2 \\
\hline Badhajal(BJ) & 60 & 30 & 60 & 150 & 6 & 2 \\
\hline Charpata (C) & 110 & 163 & 27 & 300 & 7 & 2 \\
\hline Chandijal (CJ) & 30 & 0 & 210 & 240 & 5 & 2 \\
\hline Gillnet (G) & 30 & 30 & 180 & 240 & 7 & 2 \\
\hline Hookline $(\mathrm{H})$ & 65 & 45 & 195 & 305 & 12 & 2 \\
\hline Kathijal (K) & 143 & 128 & 30 & 300 & 8 & 2 \\
\hline KhalPata (KP) & 60 & 45 & 165 & 270 & 7 & 2 \\
\hline
\end{tabular}

Table 6: Fishing time per haul, number of hauls per day, diurnal (day/night) and tidal (low/high tide) preferences for Giant Freshwater Prawn fishery in the SME of Bangladesh.

\begin{tabular}{cccccc}
\hline Gear & $\begin{array}{c}\text { Mean } \pm \text { SD } \\
\text { (Min.-Max.) } \\
\text { (hrs./haul) }\end{array}$ & $\begin{array}{c}\text { No. of } \\
\text { hauls per } \\
\text { day (no.) }\end{array}$ & $\begin{array}{c}\text { Mean active } \\
\text { hauling time } \\
\text { (hrs/day) }\end{array}$ & $\begin{array}{c}\text { Fishing } \\
\text { preference Day } \\
(\text { D)/Night }(\mathrm{N})\end{array}$ & $\begin{array}{c}\text { Suitable } \\
\text { fishing tide }\end{array}$ \\
\hline Behundijal & $4.40 \pm 2.12(8.00-2.00)$ & $2-3$ & $8.8-13.2$ & Both D and N & L/H \\
Badhajal & $4.00 \pm 00(4.00-4.00)$ & $2-3$ & $8-12$ & Both D and N & L/H \\
Charpata & $11.33 \pm 2.00(12.00-6.00)$ & 1 & 11.33 & Both D and N & L/H \\
Chandijal & $5.00 \pm 00(5.00-5.00)$ & $2-3$ & $10-15$ & Both D and N & L/H \\
Gillnet & $6.00 \pm 00(6.00-6.00)$ & 2 & 12 & Both D and N & L/H \\
Hookline & $5.67 \pm 0.52(6.00-5.00)$ & 2 & 11.34 & Both D and N & L/H \\
Kathijal & $8.75 \pm 3.77(12.00-5.00)$ & $1-2$ & $8.75-17.5$ & Both D and N & H \\
Khalpata & $6.00 \pm 0.00(6.00-6.00)$ & $1-2$ & $6-12$ & Both D and N & H \\
\hline L L & $1-2$ & & &
\end{tabular}

$\mathrm{L}=$ Low tide, $\mathrm{H}=$ High tide 
Table 7: Fisher's perceptions on Giant Freshwater Prawn catch rate by dial and lunar phases by different fishing gears

\begin{tabular}{cccccccc}
\hline \multirow{2}{*}{ Gear } & \multicolumn{3}{c}{$\begin{array}{c}\text { Higher catch time } \\
\text { (Day/Night) }\end{array}$} & \multicolumn{2}{c}{$\begin{array}{c}\text { Higher catch lunar phase } \\
\text { (Full moon/New Moon) }\end{array}$} \\
\cline { 2 - 8 } & Day & Night & No specific & Seasonal (D in Wet, & Full Moon & New & Variable \\
& $(\%)$ & $(\%)$ & pattern $(\%)$ & N in Winter) $(\%)$ & $(\%)$ & Moon $(\%)$ & $(\%)$ \\
\hline Behundijal & 00 & 00 & 20.00 & 80.00 & 80.00 & 00 & 20.00 \\
Badhajal & 00 & 00 & 00 & 100.00 & 100.00 & 00 & 00 \\
Charpata & 00 & 85.71 & 14.29 & 00 & 42.86 & 28.57 & 28.57 \\
Chandijal & 00 & 00 & 100.00 & 00 & 00 & 00 & 100.00 \\
Gillnet & 00 & 00 & 100.00 & 00 & 00 & 00 & 100.00 \\
Kathijal & 00 & 33.33 & 66.67 & 00 & 100.00 & 00 & 00 \\
Khalpata & 00 & 100.00 & 00 & 00 & 33.33 & 00 & 66.67 \\
\hline
\end{tabular}

$\mathrm{D}=$ day; $\mathrm{N}=$ night

Table 8: Hotspot areas for Giant Freshwater Prawn fishing in the SME

\begin{tabular}{llrc}
\hline Range & Location & \% of & Rank \\
& & respondents & \\
\hline Chandpai & Harbaria, Mora Passure & 48.36 & 1 \\
& Alorkol, Kokilmuni, Meherali & 16.47 & 2 \\
Khulna & Hiron point island, Sellergang & 13.2 & 3 \\
Chandpai & Jata canal & 13.2 & 3 \\
Sarankhola & Dudmukhi, Kalirchar, Nandabala II, Shela river & 11.9 & 4 \\
Sarankhola & Boya-singha, Charamukha, Horintana, Koilavala, Narkelbari gang & 6.6 & 5 \\
& Bheri, Chabrakhali, Dimerchar, Goshiangari, Kabarkhali, Khazuria, & 3.47 & 6 \\
Sarankhola & Loitakhali, Mathir gang, Nilbaria, Padmabati, Office kella, & & \\
& Patakatha, Shapkhali, Shaplakhal, Supoti & & \\
\hline
\end{tabular}


Table 9: Preferred places for Giant Freshwater Prawn fishing in SME

\begin{tabular}{lcc}
\hline Canal/River & $\begin{array}{c}\text { Generally preferred place } \\
\text { (\% of fishers) }\end{array}$ & $\begin{array}{c}\text { Preferred place for night } \\
\text { fishing (\% of fishers) }\end{array}$ \\
\hline Harbaria Canal & 28.57 & 30.77 \\
Meherali & 27.47 & 18.68 \\
Mora Passure & 5.49 & - \\
Shella River & 5.49 & - \\
Alorkol Canal & 4.40 & 3.30 \\
Jhalia Canal & 4.40 & 4.40 \\
KadererKhal & 4.40 & - \\
KhazuriaKhal & 4.40 & - \\
PangasiaKhal & 3.30 & 2.20 \\
Passure & 3.30 & - \\
Kokilmari river & 2.20 & 21.97 \\
Kopilmuni River & 2.20 & - \\
Dudmukhi River & 1.10 & 1.10 \\
JhaparKhal & 1.10 & 4.4 \\
KajraKhal & 1.10 & - \\
Narikelbaria & 1.10 & - \\
Dubla island & - & 12.09 \\
Karamjal & - & 1.10 \\
\hline Total & 100.00 & 100 \\
\hline
\end{tabular}


Table 10: Estimated daily catch rate $\left(\mathrm{kg} \mathrm{day}^{-1}\right)$ of Giant Freshwater Prawn, by different gears in SME

\begin{tabular}{|c|c|c|c|c|c|c|}
\hline Gear name & $\begin{array}{l}\text { Gear } \\
\text { No. }\end{array}$ & $\begin{array}{c}\text { Peak season } \\
\left(\mathrm{kg} \mathrm{day}^{-1} \text { gear }^{-1}\right) \\
\text { Mean } \pm \text { SD } \\
\text { (Min.-Max.) }\end{array}$ & $\begin{array}{c}\text { Lean season } \\
\left(\mathrm{kg} \mathrm{day}^{-1} \text { gear }^{-1}\right) \\
\text { Mean } \pm \text { SD } \\
\text { (Min.-Max.) }\end{array}$ & $\begin{array}{c}\text { Medium season } \\
\left(\mathrm{kg} \mathrm{day}^{-1} \text { gear }^{-1} \text { ) }\right. \\
\text { Mean } \pm \text { SD } \\
\text { (Min.-Max.) }\end{array}$ & $\begin{array}{c}\text { Annual } \\
\left(\mathrm{kg} \mathrm{boat}^{-1} \text { day }^{-1}\right) \\
\text { Mean } \pm \text { SD } \\
\text { (Min.-Max.) }\end{array}$ & $\begin{array}{l}\text { Total annual } \\
\text { catch } \\
\left(\mathrm{kg} \mathrm{boat}^{-1} \mathrm{yr}^{-1}\right)\end{array}$ \\
\hline Behundijal & 168 & $\begin{array}{l}0.50 \pm 0.15 \\
(0.29-0.91)\end{array}$ & $\begin{array}{l}0.42 \pm 0.18 \\
(0.01-0.47)\end{array}$ & $\begin{array}{c}0.47 \pm 0.77 \\
(0.12-0.52)\end{array}$ & $\begin{array}{l}0.93 \pm 0.91 \\
(0.14-0.63)\end{array}$ & $157.73 \pm 35.22$ \\
\hline Badhajal & 116 & $\begin{array}{c}1.05 \pm 0.81 \\
(0.84-1.46)\end{array}$ & $\begin{array}{c}0.94 \pm 0.13 \\
(0.18-0.99)\end{array}$ & $\begin{array}{l}1.00 \pm 0.67 \\
(0.45-1.05)\end{array}$ & $\begin{array}{l}0.99 \pm 0.27 \\
(0.48-1.16)\end{array}$ & $168.88 \pm 36.99$ \\
\hline Charpata & 162 & $\begin{array}{l}0.51 \pm 0.20 \\
(0.30-0.92)\end{array}$ & $\begin{array}{c}0.21 \pm 0.18 \\
(0.00-0.26)\end{array}$ & $\begin{array}{c}0.41 \pm 0.65 \\
(0.16-0.46)\end{array}$ & $\begin{array}{l}0.91 \pm 0.69 \\
(0.15-0.54)\end{array}$ & $156.89 \pm 51.21$ \\
\hline Chandijal & 301 & $\begin{array}{l}0.13 \pm 0.10 \\
(0.02-0.54)\end{array}$ & $\begin{array}{c}0.07 \pm 0.25 \\
(0.01-0.12)\end{array}$ & $\begin{array}{l}0.09 \pm 0.65 \\
(0.03-0.14)\end{array}$ & $\begin{array}{l}0.96 \pm 0.43 \\
(0.02-0.26)\end{array}$ & $172.24 \pm 22.45$ \\
\hline Gillnet & 169 & $\begin{array}{c}0.24 \pm 0.26 \\
(0.13-0.65)\end{array}$ & $\begin{array}{c}0.15 \pm 0.35 \\
(0.09-0.20)\end{array}$ & $\begin{array}{l}0.18 \pm 0.45 \\
(0.12-0.23)\end{array}$ & $\begin{array}{l}0.94 \pm 0.60 \\
(0.11-0.36)\end{array}$ & $166.89 \pm 64.31$ \\
\hline Hookline & 276 & $\begin{array}{l}0.20 \pm 0.21 \\
(0.09-0.61)\end{array}$ & $\begin{array}{c}0.12 \pm 0.31 \\
(0.00-0.17)\end{array}$ & $\begin{array}{l}0.16 \pm 0.97 \\
(0.10-0.21)\end{array}$ & $\begin{array}{c}0.99 \pm 0.42 \\
(0.06-0.33)\end{array}$ & $172.82 \pm 53.22$ \\
\hline Kathijal & 105 & $\begin{array}{c}1.06 \pm 0.23 \\
(0.35-1.47)\end{array}$ & $\begin{array}{l}0.95 \pm 0.17 \\
(0.13-1.00)\end{array}$ & $\begin{array}{l}0.99 \pm 0.48 \\
(0.23-1.04)\end{array}$ & $\begin{array}{c}1.00 \pm 0.96 \\
(0.24-1.17)\end{array}$ & $171.06 \pm 36.55$ \\
\hline KhalPata & 131 & $\begin{array}{c}0.59 \pm 0.30 \\
(0.21-1.00)\end{array}$ & $\begin{array}{l}0.29 \pm 0.66 \\
(0.07-0.34)\end{array}$ & $\begin{array}{c}0.39 \pm 0.84 \\
(0.13-0.44)\end{array}$ & $\begin{array}{l}0.84 \pm 0.84 \\
(0.13-0.59)\end{array}$ & $152.08 \pm 61.52$ \\
\hline
\end{tabular}


Table 11: Estimated rate of Giant Freshwater Prawn catch per unit effort (CPUE) by using different gears

\begin{tabular}{|c|c|c|c|c|c|c|c|c|c|}
\hline CPUE & $\begin{array}{l}\text { Fishing } \\
\text { season }\end{array}$ & Behundijal & Badhajal & Charpata & Chandijal & Gill net & Hookline & Kathijal & KhalPata \\
\hline \multirow{4}{*}{$\begin{array}{l}\text { Mean } \pm \text { SD of } \\
\text { CPUE } \\
\text { (kg/boat/day) }\end{array}$} & $\mathrm{Pe}$ & $1.00 \pm 0.014$ & $1.05 \pm 0.22$ & $1.24 \pm 0.74$ & $1.29 \pm 0.76$ & $1.19 \pm 0.99$ & $1.24 \pm 1.20$ & $1.06 \pm 1.32$ & $1.17 \pm 1.33$ \\
\hline & Lean & $0.84 \pm 0.68$ & $0.94 \pm 0.15$ & $0.50 \pm 0.36$ & $0.69 \pm 0.34$ & $0.74 \pm 0.25$ & $0.75 \pm 0.65$ & $0.95 \pm 1.02$ & $0.57 \pm 0.98$ \\
\hline & Medium & $0.93 \pm 0.63$ & $1.00 \pm 1.25$ & $0.99 \pm 1.36$ & $0.89 \pm 0.58$ & $0.89 \pm 0.75$ & $0.99 \pm 0.98$ & $0.99 \pm 1.12$ & $0.77 \pm 0.65$ \\
\hline & Annual & $0.93 \pm 0.08$ & $0.99 \pm 0.06$ & $0.91 \pm 0.37$ & $0.96 \pm 0.31$ & $0.94 \pm 0.23$ & $0.99 \pm 0.25$ & $1.00 \pm 0.06$ & $0.84 \pm 0.31$ \\
\hline \multirow{4}{*}{$\begin{array}{l}\text { Mean } \pm \text { SD of } \\
\text { CPUE(kg/boat/trip) }\end{array}$} & Peak & $7.01 \pm 4.25$ & $7.33 \pm 3.17$ & $8.65 \pm 6.25$ & $9.04 \pm 4.12$ & $8.34 \pm 2.63$ & $8.67 \pm 1.65$ & $7.43 \pm 6.35$ & $8.20 \pm 3.52$ \\
\hline & Lean & $5.89 \pm 1.69$ & $6.56 \pm 2.65$ & $3.52 \pm 1.25$ & $4.84 \pm 0.99$ & $5.19 \pm 2.45$ & $5.22 \pm 2.11$ & $6.66 \pm 3.12$ & $4.00 \pm 1.22$ \\
\hline & Medium & $6.52 \pm 3.22$ & $6.98 \pm 2.14$ & $6.94 \pm 3.24$ & $6.24 \pm 1.65$ & $6.24 \pm 1.65$ & $6.94 \pm 1.65$ & $6.94 \pm 1.65$ & $5.40 \pm 2.35$ \\
\hline & Annual & $6.48 \pm 0.56$ & $6.95 \pm 0.39$ & $6.37 \pm 2.61$ & $6.71 \pm 2.14$ & $6.59 \pm 1.60$ & $6.94 \pm 1.73$ & $7.01 \pm 0.39$ & $5.87 \pm 2.14$ \\
\hline \multirow{4}{*}{$\begin{array}{l}\text { Mean } \pm \text { SD of } \\
\text { CPUE } \\
\text { (kg/boat/season) }\end{array}$} & Peak & $86.15 \pm 36.25$ & $90.02 \pm 54.25$ & $106.32 \pm 43.69$ & $111.09 \pm 15.36$ & $102.49 \pm 32.25$ & $106.51 \pm 26.35$ & $91.31 \pm 22.14$ & $100.77 \pm 26.33$ \\
\hline & Lean & $15.84 \pm 11.03$ & $16.95 \pm 8.12$ & $16.86 \pm 9.21$ & $15.16 \pm 10.24$ & $15.16 \pm 11.31$ & $16.86 \pm 4.11$ & $16.86 \pm 7.22$ & $13.12 \pm 6.32$ \\
\hline & Medium & $54.72 \pm 31.22$ & $60.89 \pm 23.41$ & $32.69 \pm 21.21$ & $44.97 \pm 28.25$ & $48.22 \pm 24.66$ & $48.43 \pm 17.21$ & $61.87 \pm 24.22$ & $37.17 \pm 11.14$ \\
\hline & Annual & $52.24 \pm 35.22$ & $55.95 \pm 36.79$ & $51.96 \pm 47.74$ & $57.07 \pm 49.10$ & $55.29 \pm 44.09$ & $57.27 \pm 45.47$ & $56.68 \pm 37.50$ & $50.35 \pm 45.29$ \\
\hline \multirow{4}{*}{$\begin{array}{l}\text { Mean } \pm \text { SD of } \\
\text { CPUE }(\mathrm{kg} / \text { day } / \text { man })\end{array}$} & Peak & $0.50 \pm 0.14$ & $0.52 \pm 0.12$ & $0.35 \pm 0.11$ & $0.22 \pm 0.38$ & $0.30 \pm 0.37$ & $0.62 \pm 0.39$ & $0.18 \pm 0.20$ & $0.39 \pm 0.32$ \\
\hline & Lean & $0.42 \pm 0.32$ & $0.47 \pm 0.14$ & $0.14 \pm 0.16$ & $0.12 \pm 0.33$ & $0.19 \pm 0.14$ & $0.37 \pm 0.40$ & $0.16 \pm 0.19$ & $0.19 \pm 0.33$ \\
\hline & Medium & $0.47 \pm 0.52$ & $0.50 \pm 0.36$ & $0.28 \pm 0.19$ & $0.15 \pm 0.21$ & $0.22 \pm 0.53$ & $0.50 \pm 0.25$ & $0.17 \pm 0.14$ & $0.26 \pm 0.37$ \\
\hline & Annual & $0.46 \pm 0.04$ & $0.50 \pm 0.03$ & $0.26 \pm 0.11$ & $0.16 \pm 0.05$ & $0.24 \pm 0.06$ & $0.50 \pm 0.12$ & $0.17 \pm 0.01$ & $0.28 \pm 0.10$ \\
\hline
\end{tabular}

Peak season = December, January and February (full dry winter season); Lean season = May, June, July and August (one third of pre-monsoon and three fourth of monsoon); Medium season = March, April, September, October and November (two third of the pre-monsoon and full of the post-monsoon) 
